\title{
Think-Pair-Square (TPS), sebuah Model Pembelajaran Kooperatif dalam Meningkatkan Aktivitas dan Prestasi Belajar Siswa
}

\author{
Nathasa Pramudita Irianti ${ }^{1}$, Elita Mega Selvia Wijaya ${ }^{2}$ \\ Pendidikan Matematika FIP Universitas Tribhuwana Tunggadewi ${ }^{1,2}$ \\ E-mail: nathasa1990@gmail.com ${ }^{1}$
}

\begin{abstract}
Abstrak
Tujuan penelitian adalah untuk mengetahui efektivitas pembelajaran Think Pair Square (TPS) terhadap peningkatan aktivitas dan prestasi belajar siswa. Jenis penelitian yang digunakan adalah Penelitian Tindakan Kelas (PTK) yang dilaksanakan dalam 2 siklus. Bentuk tindakan pada siklus I merupakan perbaikan untuk tindakan pada siklus II. Tindakan yang diberikan adalah penerapan model pembelajaran TPS. Penerapan pembelajaran ini terlaksana dengan baik. Hal ini dapat ditunjukkan pada tahap berfikir, berpasangan dan berempat di siklus I yang belum terlaksana dengan baik dan lancar menjadi lebih baik pada siklus II. Aktivitas belajar siswa mengalami peningkatan dari siklus I ke siklus II pada kategori baik dengan persentase rata-rata aktivitas siswa pada siklus I sebesar 7\% untuk kategori K (Kurang); 54\% untuk tingkat C (Cukup) dan 39\% pada kategori $B$ (Baik), mengalami peningkatan ke kategori baik ditandai dengan berkurangnya jumlah siswa yang mencapai kategori $K$ dan $C$, yaitu rata-rata aktivitas siswa pada siklus II sebesar 0\% untuk kategori K (Kurang); 46,5\% untuk kategori $C$ (Cukup) dan 53,5\% pada kategori B (Baik). Prestasi belajar mengalami peningkatan dari siklus I ke siklus II, ditandai oleh peningkatan skor tes tulis rata-rata siswa sebesar 6,95 $(9,55 \%)$ dan peningkatan persentase ketuntasan belajar sebesar $45 \%$ dari $40 \%$ menjadi $85 \%$.
\end{abstract}

Kata kunci: Model Pembelajaran TPS, Aktivitas Belajar, Prestasi Belajar.

\begin{abstract}
The purpose of this research is to know the effectiveness of Think Pair Square (TPS) learning to increase student activity and achievement. The type of research used is Action Research which is implemented in 2 cycles. The form of action in cycle $\mathrm{I}$ is an improvement for action in cycle II. The action given is the application of the TPS learning model. The implementation of this learning is done well. This can be shown in the thinking, coupling and quartile stages in cycle I that have not been done well and smoothly for the better in cycle II. Student learning activity increased from cycle I to cycle II in good category with the average percentage of student activity in cycle I of $7 \%$ for category $\mathrm{K}$ (Less); 54\% for level C (Enough) and 39\% in category B (Good), improved to good category marked by decreasing number of student reaching category $\mathrm{K}$ and $\mathrm{C}$, that is average student activity in cycle II $0 \%$ for category $\mathrm{K}$ (Less); 46,5\% for category $\mathrm{C}$ (moderate) and 53,5\% in category B (Good). The learning achievement has increased from cycle I to cycle II, seen by the increase of average student writing score of $6.95(9.55 \%)$ and the percentage improvement of learning mastery by $45 \%$ from $40 \%$ to $85 \%$.
\end{abstract}

Keywords: Think Pair Square's Learning Model, Learning Activity, Learning Achievement. 


\section{Informasi Tentang Artikel}

\begin{tabular}{l} 
Diterima pada \\
Disetujui pada \\
Diterbitkan \\
\hline PENDAHULUAN \\
Matematika sebagai salah satu \\
mata pelajaran di sekolah dinilai cukup \\
memegang peranan penting dalam \\
membentuk siswa menjadi berkualitas \\
(Frensista, 2014). Namun pada \\
kenyataannya matematika sering dianggap \\
sebagai mata pelajaran yang sulit untuk \\
dimengerti. Indikasinya dapat dilihat dari \\
siswa yang kurang aktif dalam proses \\
belajar mengajar dan juga menurunnya \\
prestasi belajar siswa khususnya di \\
pelajaran matematika.
\end{tabular}

Berdasarkan observasi dan wawancara dengan guru Matematika di SMP Negeri 21 Malang kelas VIII $_{D}$ diperoleh informasi bahwa situasi kelas dan metode pembelajaran yang digunakan di kelas masih didominasi oleh guru. Sedangkan siswa hanya mendengarkan, mencatat materi yang disampaikan oleh guru, jarang bertanya dan menanggapi pertanyaan guru. Melihat situasi yang demikian dapat dikatakan bahwa proses belajar mengajar matematika kurang efektif dan maksimal.

Hal serupa juga ditemui dalam penelitian Wara (2012) yang juga menemukan bahwa guru masih menggunakan metode ceramah dalam memberikan materi matematika. Dari dua hal tersebut, nampak bahwa aktivitas belajar siswa masih sangatlah rendah, sehingga menyebabkan siswa merasa bosan, mengantuk, bermain sendiri, berbicara hal-hal di luar materi pelajaran dengan teman sebangkunya, tidak memperhatikan penjelasan yang disampaikan oleh guru dan kemauan siswa untuk belajar masih kurang. Dampak lain dari yang tersebut di atas adalah kurangnya kemandirian siswa, yang dapat membuat guru sangat sulit untuk membangkitkan aktivitas belajar siswa. Peran utama proses pembalajaran yang berada di tangan guru

: 25 November 2017

: 27 Desember 2017

: Januari 2018

ini menyebabkan guru hanya

menyampaikan semua informasi dan pengetahuan yang dia miliki kepada siswa, sehingga menyebabkan guru kurang optimal dalam melakukan interaksi langsung dengan siswanya. Sedangkan siswa hanya mendengarkan, mencatat materi yang disampaikan oleh guru, jarang bertanya dan menanggapi pertanyaan guru. Situasi yang demikian dapat dikatakan bahwa proses belajar mengajar matematika kurang efektif dan maksimal.

Salah satu model Cooperative Learning adalah tipe Think Pair Square. Think Pair Square (TPS) merupakan salah satu model pembelajaran yang dikembangkan dari teori kontrukivisme yang merupakan perpaduan antara belajar secara mandiri dan belajar secara berkelompok (Karyawati, 2014). Model Cooperative Learning tipe Think Pair Square ini dapat memberi siswa kesempatan untuk bekerja sendiri serta bekerja sama dengan orang lain. Menurut Anita (2010: 58), langkah-langkah dalam model Cooperative Learning Tipe Think Pair Square yaitu: (1) Guru membagi siswa dalam kelompok berempat dan memberikan tugas kepada semua kelompok, (2) Setiap siswa mengerjakan dan memikirkan tugas itu sendiri, (3) Setiap siswa berpasangan dengan salah satu teman dalam kelompok dan berdiskusi dengan pasangannya, (4) Kedua pasangan bertemu kembali dalam kelompok berempat dan semua siswa mendapat kesempatan untuk membagi hasil kerjanya dalam kelompok. Berdasarkan pendapat di atas, berarti setelah guru membagi siswa dalam kelompok berempat, ada tiga tahapan pembelajaran yang dilalui, yaitu: "Think" yang memberi kesempatan setiap siswa untuk berfikir individu, "Pair" dimana siswa saling bertukar pikiran dengan pasangannya. Secara psikologis, 
siswa akan lebih merasa nyaman bertanya ataupun berdiskusi dengan sesamanya (Lie, 2002). Erman (2003: 277) menjelaskan bahwa bahasa teman sebaya lebih mudah dipahami, dengan teman sebaya tidak ada rasa enggan, rendah diri, malu dan sebagainya untuk bertanya ataupun minta bantuan. Tahap ketiga yaitu "Square" dimana siswa saling berbagi dan berdiskusi dengan anggota kelompok berempat.

Berdasarkan latar belakang di atas, masalah penelitian difokuskan pada keefektifan pembelajaran Think Pair Square terhadap aktivitas dan prestasi belajar siswa.

\section{METODE PENELITIAN}

Penelitian ini menggunakan pendekatan kualitatif dan jenis penelitian ini adalah penelitian tindakan kelas (PTK) dengan memberikan tindakan berupa pembelajaran kooperatif model Think Pair Square. Subjek penelitiannya adalah siswa kelas VIII Demester II SMP Negeri 21 Malang yang berjumlah 40 siswa yang terdiri dari 17 siswa laki-laki dan 23 siswa perempuan.

Tahapan penelitian dilakukan dengan menggunakan siklus yang terdiri dari perencanaan, tindakan, observasi, evaluasi dan refleksi. Penelitian tindakan kelas dilaksanakan dalam 2 siklus. Bentuk tindakan pada siklus I merupakan perbaikan untuk tindakan pada siklus II. Instrumen penelitian yang digunakan yaitu lembar observasi keterlaksanaan pembelajaran, lembar aktivitas belajar siswa dan tes tulis.

Data dalam penelitian ini bersifat kualitatif. Analisis data pada penelitian ini meliputi: (a) Reduksi data adalah proses penyederhanaan yang dilakukan melalui seleksi pemfokusan dan pengabstraksian data mentah menjadi informasi yang bermakna. (b) Penyajian data, data yang sudah diklasifikasikan dan disederhanakan, dideskripsikan dalam bentuk kata-kata yang bermakna, dan (c) Penarikan kesimpulan adalah pengambilan intisari dari sajian data yang berupa kalimat singkat padat tetapi mengandung pengertian luas yang mewakili keseluruhan. Data penelitian ini dikumpulkan dengan tiga cara yakni tes tulis (untuk prestasi belajar), lembar observasi aspek aktivitas belajar, dan lembar observasi keterlaksanaan pembelajaran. Keterlaksanaan model pembelajaran bersifat kualitatif. Sedangkan prestasi belajar bersifat kuantitatif (berupa angka).

\section{HASIL DAN PEMBAHASAN \\ Keterlaksanaan pembelajaran dengan model TPS pada Siklus I dan Siklus II}

Kegiatan pembelajaran siklus I belum terlaksana sesuai rencana, masih ada tahapan yang belum terlaksana secara maksimal. Menentukan hubungan dua garis untuk mengawali tahap berfikir (think) belum terlaksana, sehingga membuat siswa bingung, alur penyampaian materi menjadi tidak urut, dan berkurangnya aktivitas siswa dalam kelas. Pada tahap berpasangan (pair), beberapa siswa masih terlihat berusaha melihat jawaban pasangan lain dan belum bisa mengoptimalkan waktu yang diberikan guru. Pada tahap berempat (square) saat berdiskusi siswa belum bisa memanfaatkan waktu yang diberikan dengan baik dan tepat. Belum maksimalnya pelaksanaan pembelajaran pada siklus I ini, mungkin juga disebabkan karena siswa baru mengenal dan mengetahui cara belajar dengan model ini, sehingga mereka membutuhkan adaptasi terlebih dahulu.

Proses pelaksanaan siklus II secara umum sudah baik dan sesuai dengan rencana pelaksanaan pembelajaran yang dibuat. Pada siklus II untuk tahap berfikir (Think) terlaksana semua dengan baik, hal ini karena guru sudah mengambil pengalaman berharga dari siklus I. Tahap berpasangan (Pair) pada siklus II guru telah terlaksana keseluruhan dengan baik. Guru mampu membuat siswa berinteraksi, berkomunikasi dan belajar dalam bentuk 
berpasangan. Siswa berkomunikasi dengan pasangannya untuk memecahkan dan mencocokkan jawaban masalah yang sebelumnya sudah mereka pikirkan sendiri. Tahap berempat juga terlaksana semua dengan baik Tahap berbagi dengan kelas pada siklus II seluruhnya terlaksana. Siswa sudah bisa melakukan presentasi, diskusi, dan juga penyimpulan diskusi dengan baik, walaupun pada siklus I siswa masih terkesan malu dan ragu-ragu namun pada siklus II siswa sudah bisa melakukannya dengan baik dan lancar. Tes yang dilakukan pada siklus I dan II berjalan dengan baik. Penghargaan kelompok dilakukan setelah selesai melakukan tes. Penghargaan kelompok ini dimaksudkan untuk memberi semangat dan lebih memacu untuk bersungguhsungguh dalam pembelajaran. Kelompok dengan nilai rata-rata tertinggi yang mendapatkan penghargaan.

\section{Penerapan Pembelajaran Kooperatif Model TPS terhadap Aktivitas Belajar SiswaData Aktivitas Belajar Siswa pada Siklus I dan Siklus II}

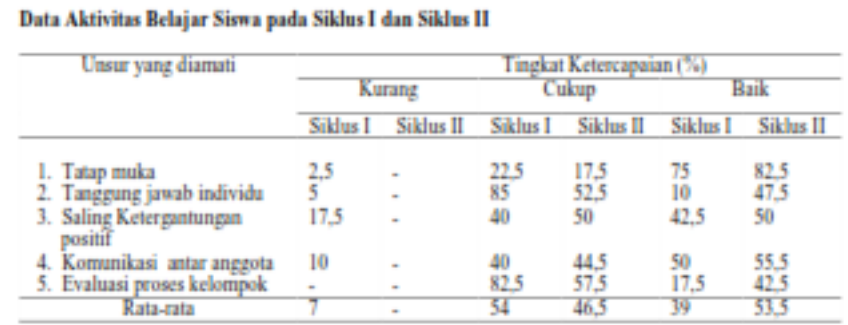

Aspek tatap muka dari siklus I ke siklus II mengalami peningkatan pada kategori baik, yaitu sebesar 7,5\% sedangkan untuk kategori kurang dan cukup, aspek tatap muka mengalami penurunan masing-masing sebesar 2,5\% dan 5\%. Penurunan ini menunjukkan bahwa pada saat diskusi siswa segera mencari dan berkumpul dengan anggotanya serta siswa sudah duduk berhadapan saat diskusi. Aspek tanggung jawab individu dari siklus I ke siklus II mengalami peningkatan pada kategori baik yaitu sebesar $37,5 \%$, sedangkan pada kategori kurang dan cukup, aspek tanggung jawab individu mengalami penurunan masing-masing sebesar 5\% dan $32,5 \%$. Penurunan ini menunjukkan bahwa siswa sudah mengerjakan LKS dan siswa dapat menjelaskan kepada kelompoknya tentang materi yang menjadi tugasnya. Aspek saling ketergantungan positif dari siklus I ke siklus II mengalami peningkatan pada kategori baik dan cukup masing-masing sebesar $7,5 \%$ dan $10 \%$, sedangkan untuk kategori kurang mengalami penurunan sebesar $17,5 \%$. Penurunan pada kategori tersebut menunjukkan bahwa siswa sudah bisa bertanggung jawab untuk menyelesaikan tugas yang diberikan kepadanya, aktif bertanya, dan memberikan pendapatnya saat diskusi. Aspek komunikasi antar anggota dari siklus I ke siklus II mengalami peningkatan pada kategori baik dan cukup masing-masing sebesar 5,5\% dan $4,5 \%$, sedangkan pada kategori kurang mengalami penurunan sebesar $10 \%$. Hal ini menunjukkan bahwa siswa sudah mengajukan pendapat, mengajukan pertanyaan dengan jelas, dan mau mendengarkan penjelasan anggota kelompoknya pada saat diskusi. Aspek evaluasi proses kelompok mengalami peningkatan pada kategori baik, yaitu sebesar $25 \%$ sedangkan pada kategori kurang tidak mengalami peningkatan ataupun kenaikan (tetap), dan pada kategori cukup mengalami penurunan sebesar $25 \%$. Hal ini menunjukkan bahwa siswa berpartisipasi dalam kerja kelompok, tepat waktu dalam menyelesaikan tugas yang diberikan kepadanya, dan mampu membuat kesimpulan berdasarkan tujuan diskusi.

Berdasarkan pembahasan yang telah dipaparkan di atas, penggunaan metode pembelajaran kooperatif Think Pair Square dapat meningkatkan aktivitas belajar siswa. Hal ini dapat dilihat dari aktivitas belajar siswa dari siklus I ke siklus II yang mengalami kenaikan pada kategori baik, walaupun kenaikan yang terjadi tidak besar. 
Penerapan Pembelajaran Kooperatif Model TPS terhadap Prestasi Belajar Siswa

Data Nilai Tes Tulis Rata-Rata pada Observasi Awal, Siklus I, dan Siklus II

\begin{tabular}{lccc}
\hline \multicolumn{1}{c}{ Tes } & Nilii Tes Tulis Rata-rata & Kenaikan & Persentase (76) Kenaikan \\
\hline Observasi Aual & 59,63 & & \\
Siklus I & 72,75 & 13,12 & 22 \\
Siklus II & 79,70 & 6,95 & 9,55 \\
\hline
\end{tabular}

Data Persentase Ketuntasan Belajar Siswa Sebelum Tindakan, Siklus I, dan Siklus II

\begin{tabular}{|c|c|c|c|}
\hline Sloer & Scbelum Tindakan & Siklus I & Siklus II \\
\hline$\geq 72$ (funtas) & $4 \operatorname{sic} 2(10 \%)$ & 16 siswa $(40 \%)$ & 34 siswa $(85 \%)$ \\
\hline$\leq 71$ (belum tuntes) & 36 siswa (90\%) & 24 siswa (60) $\%$ ) & 6 siswa (15\%) \\
\hline
\end{tabular}

Prestasi belajar siswa dapat dilihat dari nilai tes tulis rata-rata dan persen-tase ketuntasan belajar siswa. Nilai tes tulis rata-rata siswa dari tes pada observasi awal, dan siklus I masing-masing sebesar 59,63 dan 72,75 . Hal ini berarti terjadi peningkatan nilai tes tulis rata-rata sebesar 13,12 (22\%). Begitu juga untuk ketuntasan belajar siswa dari sebelum tindakan ke siklus I mengalami peningkatan, yaitu dari $10 \%$ menjadi $40 \%$, hal ini berarti terjadi peningkatan sebesar $30 \%$. Peningkatan yang terjadi disebabkan siswa yang biasanya belajar dengan menggunakan metode ceramah dan guru yang menjadi peran utama berganti menjadi pembelajaran yang mengusahakan agar siswa menjadi lebih aktif, sehingga siswa akan lebih memahami materi yang akan diajarkan. Siswa dapat memahami materi karena pada awalnya siswa yang memikirkan dan mencari jawaban dari permasalahan yang diberikan guru dimana permasalahan-permasalahan yang diberikan guru tersebut bersangkutan dengan materi yang akan dipelajari siswa pada hari tersebut. Nilai tes tulis rata-rata siswa dari tes pada siklus I dan siklus II masingmasing sebesar 72,75 dan 79,70. Hal ini berarti terjadi peningkatan nilai tes tulis rata-rata sebesar 6,95 (9,55\%). Peningkatan juga terjadi pada ketuntasan belajar dari siklus I ke siklus II, yaitu sebagai berikut: dari $40 \%$ (siklus I) menjadi $85 \%$ (siklus II), berarti terjadi peningkatan ketuntasan belajar siswa ini sebesar $45 \%$, peningkatan ini lebih baik dari sebelumnya yang hanya $30 \%$. Peningkatan yang lebih baik ini disebabkan pada siklus II siswa sudah mengerti dan mulai terbiasa dengan penerapan model pembelajaran TPS yang diterapkan, sehingga siswa dapat belajar dengan maksimal.

Berdasarkan uraian di atas yang menyatakan bahwa mulai sebelum tindakan ke siklus I sampai dengan ke siklus II yang terus mengalami peningkatan, selanjutnya apabila model TPS terus diterapkan, kemungkinan prestasi belajar siswa akan lebih meningkat lagi.

\section{SIMPULAN}

Penerapan pembelajaran dengan model pembelajaran TPS melalui empat tahapan meliputi berfikir (think), berpasangan (pair), berempat (square), dan berbagi dalam kelas, terlaksana dengan baik. Penerapan pembelajaran dengan model pembelajaran TPS dapat meningkatkan aktivitas belajar siswa. Hal ini ditunjukkan dengan persentase rata-rata aktivi-tas siswa pada siklus I sebesar 7\% untuk kategori K (Kurang); 54\% untuk kategori C (Cukup) dan 39\% pada kategori B (Baik), sedangkan pada siklus II mengalami peningkatan ke kategori baik dengan berkurangnya jumlah siswa yang mencapai kategori $\mathrm{K}$ dan $\mathrm{C}$. Persentase rata-rata aktivitas siswa pada siklus II sebesar 0\% untuk kategori K (Kurang); 46,5\% untuk kategori C (Cukup) dan 53,5\% pada kategori B (Baik). Penerapan pembelajaran dengan model pembelajaran TPS dapat meningkatkan prestasi belajar siswa. Hal ini ditunjukkan dari siklus I ke siklus II yang mengalami peningkatan untuk skor tes tulis rata-rata siswa sebesar $6,95(9,55 \%)$ dan peningkatan persentase ketuntasan belajar sebesar $45 \%$ dari $40 \%$ menjadi $85 \%$. 
DAFTAR PUSTAKA

Anita, L. 2010. Cooperative Learning. Jakarta: PT. Gramedia

Erman, Suherman dkk. 2003. Strategi Pembelajaran Matematika Kontemporer. Bandung: FMIPA UPI

Frensista, Dina. 2014. Penerapan Model Pembelajaran Kooperatif dengan Strategi Rotating Trio Exchange untuk Meningkatkan Hasil Belajar Siswa Kelas VII A pada Sub Pokok Bahasan Keliling dan Luas Bangun Segitiga dan Segiempat di SMP Negeri 1 Ajung Semester Genap Tahun Ajaran 2012/2013. Pancaran. Vol.3 No.2
Karyawati, Ni Komang. 2014. Pengaruh Model Pembelajaran Kooperatif Tipe Think Pair Square (TPS) Berbantuan Kartu Kerja Terhadap Hasil Belajar Matematika. Jurnal Mimbar PGSD Universitas Pendidikan Ganesha Jurusan PGSD. Vol. 2 No. 1

Lie, A. 2002. Mempraktekkan Cooperatif Learning Di Ruang-Ruang Kelas. Jakarta: PT. Gramedia.

Wara, J. Michelin. 2012. Model

Cooperative Learning Tipe Think Pair Square dalam Pembelajaran Matematika di Kelas VII SMPN 1 Pulau Punjung. Jurnal Pendidikan Matematika. Vo. 1 No. 2 